\title{
Screening of medicinal plants for antibacterial activities on Staphylococcus aureus strains isolated from bovine mastitis
}

\author{
Marisa A. N. Diaz, ${ }^{*}$, Ciro C. Rossi, ${ }^{1}$ Vítor R. Mendonça, ${ }^{1}$ Danielle M. Silva, ${ }^{1}$ \\ Andréa de O. B. Ribon, ${ }^{1}$ Ananda P. Aguilar, ${ }^{1}$ Gaspar D. Muñoz ${ }^{2}$
}

\author{
${ }^{1}$ Departamento de Bioquímica e Biologia Molecular, Centro de Ciências Biológicas e da Saúde, Universidade \\ Federal de Viçosa, Avenida Peter Henry Rolfs s/n, Campus Universitário, 36570-000 Viçosa-MG, Brasil, \\ ${ }_{2}^{2}$ Instituto de Ciências Exatas, Universidade Federal de Minas Gerais, Av. Antônio Carlos, 6627, Pampulha, \\ 31270-901 Viçosa-MG, Brasil.
}

\begin{abstract}
RESUMO: "Screening de plantas medicinais com atividade antimicrobiana contra cepas de Staphylococcus aureus isoladas de mastite bovina". Staphylococcus aureus é o principal agente causador de mastite bovina. A atividade de diversos extratos de dez plantas medicinais tradicionalmente usadas no Brasil como anti-sépticas foi investigada contra quinze cepas de Staphylococcus aureus isoladas de animais com manifestação de mastite pelo método de difusão em ágar e ensaio de microdiluição. A interferência dos extratos na célula bacteriana em forma de colônias aderidas também foi avaliada. Os valores de MIC variaram de $0.5 \mathrm{mg} / \mathrm{mL}$ a $1.0 \mathrm{mg} / \mathrm{mL}$ e a concentração inibitória de biofilme (BIC) variou de $0.25 \mathrm{mg} / \mathrm{mL}$ a $0.8 \mathrm{mg} / \mathrm{mL}$. Os resultados revelaram o potencial dos extratos de Senna macranthera, Artemisia absinthium, Cymbopogon nardus e Baccharis dracunculifolia como agentes antibacterianos contra cepas de S. aureus isolados de mastite bovina e suportam o possível uso destas plantas no manejo clínico da doença.
\end{abstract}

Unitermos: Staphylococcus aureus, mastite bovina, plantas medicinais, medicina tradicional, inibição de biofilme.

\begin{abstract}
Staphylococcus aureus is the main causative agent of bovine mastitis. The activity of several extracts from ten medicinal plants traditionally used in Brazil as antiseptic was investigated against fifteen strains of Staphylococcus aureus isolated from animals with mastitis manifestation by the disc diffusion method and broth microdilution assay. The interference of the extracts on cell in the form of adherent colonies was also evaluated. MIC values ranged from $0.5 \mathrm{mg} / \mathrm{mL}$ to $1.0 \mathrm{mg} /$ $\mathrm{mL}$ and biofilm inhibitory concentration (BIC) were between $0.25 \mathrm{mg} / \mathrm{mL}$ and $0.8 \mathrm{mg} / \mathrm{mL}$. Results revealed the potential of extracts of Senna macranthera, Artemisia absinthium, Cymbopogon nardus and Baccharis dracunculifolia as antibacterial agents against S. aureus strains isolated from bovine mastitis and support the possible use of these phytotherapic agents in the clinical management of the disease.
\end{abstract}

Keywords: Staphylococcus aureus, bovine mastitis, medicinal plants, folk medicine, biofilm inhibition.

\section{INTRODUCTION}

Medicinal plants have been used for ages in developing countries as alternative treatment to health problems. Brazil has a diverse flora and a rich tradition in the use of medicinal plants for antimicrobial applications (Sartoratto et al., 2004). Many plant extracts have been shown to exert biological activity in vitro and in vivo, justifying research on traditional medicine focused on the characterization of antimicrobial activity of these plants (Gullece et al., 2006). The importance of using medicinal plants can be attributed to affordability as well as the trust in herbal medicine as an outcome from the witnessed positive results when applying herbs. Many medicinal plants are also used to treat cows, sheep, poultry, horses and pigs (Marinho et al., 2007). Viçosa is a small town located in the state of Minas Gerais, Southeastern Brazil, where dairy activities play an important role in the livelihood of the community from rural area. In this area, mastitis is also the most prevalent dairy health problem. Staphylococcus aureus is the main causatitive agent of bovine mastitis and it's commonly associated to chronic infections (Hebert et al., 2000). S. aureus presents high resistance to adverse environmental conditions, which makes it a very important 
pathogen. Many chronic infections are associated with bacterial growth in the form of adherent colonies involved by an exopolysaccharide matrix, constituting a biofilm (Cucarella et al., 2004). Due to its aggregated form, some biofilms are not susceptible to phagocytosis and become resistant to some antibiotics (Monzon et al., 2002). It is a key role in the establishment of persistent infections caused by Staphylococcus aureus and it is a limiting factor in the treatment of bovine mastitis. Conventional therapeutics is usually based in antibiotics that are not always effective as bacteria become resistant. Besides, its residues can affect human health and interfere in fermentation processes in the milk industry. This motivated the search for new antimicrobial agents and the study of natural plant products as substitutes for chemical antimicrobial agents (Pandian et al., 2006). Medicinal plants were reported by local farmers to be used for increased production of milk and for treatment of bovine mastitis. This work is a step towards exploring the potential use of these medicinal plants indicated. Likewise, other plants traditionally used for treatment of tropical diseases and antimicrobial application for infectious diseases were also screened against strains of Staphylococcus aureus isolated from bovine mastitis to evaluated their use in the clinical management of the disease as phytotherapic agent.

\section{MATERIALS AND METHODS}

Aerial parts of the medicinal plants Artemisia absinthium L. (voucher 15614); Cymbopogon nardus L. Rendle (voucher 30283); Symphytum officinale L. (voucher 24060); Baccharis dracunculifolia DC. (voucher 31322); Solanum asperolanatum Ruiz \& Pav (voucher 11609); Salvia officinalis L. (voucher 1240); Bauhinia forficata Link (voucher 15128); Calendula officinalis L (voucher 15593) and Chenopodium ambrosioides L. (voucher 11762) were collected in Viçosa-MG, Brazil, identified and deposited at the herbarium of the Department of Botany of the Federal University of Viçosa. Senna macranthera (Collad.) Irwin et Barn. flowers (voucher 1237) were colleted in CascavelPR, Brazil, identified and deposited at the herbarium of the Department of Botany of at State University of West of Paraná. The plants were dried under shade in open air to reduce deterioration of the plant drug material.

The air-dried plant material was weighed and $250 \mathrm{~g}$ of each plant sample was extracted exhaustively and consecutively by using $n$-hexane, dichloromethane and ethanol, and $250 \mathrm{~g}$ of the seven plants indicated by the farmers were also extracted, additionally, using ethanol/ water $80: 20$ as suggested by them. The extracts were dried under reduced pressure at about $40{ }^{\circ} \mathrm{C}$. Stock solutions of the extracts were prepared in dimethylsuphoxide (DMSO).

The extracts produced were tested against fifteen Staphylococcus aureus strains isolated from animals with occurrence of mastitis cases reported in southeastern
Brazil. The isolates were previously grown in $3 \mathrm{~mL}$ of brain heart infusion broth (BHI) for $16 \mathrm{~h}$ at $37^{\circ} \mathrm{C}$ for the biological tests realization.

In order to make the screening of antibacterial activity of the extracts, suspension of the bacteria containing $10^{6} \mathrm{UFC} / \mathrm{mL}$ was spread on Müeller Hinton agar and dried at room temperature. Filters paper disks impregnated with each plant extract stock sollution were then placed on the plates, followed by $24 \mathrm{~h}$ of incubation at $37^{\circ} \mathrm{C}$. After incubation, the inhibition zones were measured in millimeters. Clear inhibition zones around the disks with $7 \mathrm{~mm}$ or higher of diameter were considered as positive susceptibility (Leite et al., 2000). Ciclopirox olamine $(10 \mathrm{mg} / \mathrm{mL})$ was used as positive control and DMSO as negative control. The experiments were repeated twice in triplicate.

The broth microdilution method was used for determination of the minimum inhibitory concentration (MIC) of those extracts which showed activity. The 96 well plates were prepared by dispensing an aliquot of 180 $\mu \mathrm{L}$ of Müeller Hinton broth followed by $20 \mu \mathrm{L}$ inoculum containing $10^{6} \mathrm{UFC} / \mathrm{mL}$. The stock extracts solutions were dispensed in corresponding positions to concentrations from $5 \mu \mathrm{g} / \mathrm{mL}$ to $3.0 \mathrm{mg} / \mathrm{mL}$. The microplates were incubated at $37{ }^{\circ} \mathrm{C}$ for $24 \mathrm{~h}$. The MIC was defined as the lowest concentration of the extract at which the microorganism didn't show visible growth. Ciclopirox olamine $(10 \mathrm{mg} /$ $\mathrm{mL}$ ) was used as positive control and DMSO as negative control. Experiments were conducted in triplicate.

The effect of subinhibitory concentrations of the active extracts on established biolfilms was evaluated according to Johnson et al. (2002) and Nostro et al. (2007) with some modifications. The isolates were grown in BHI in a polystyrene flatbottomed microtitre plate in order to form biofilm after $24 \mathrm{~h}$ of incubation at $37^{\circ} \mathrm{C}$. The supernatant cells were removed with a micropipette and the wells were washed with saline solution $0,85 \%$ for three times and filled with $200 \mathrm{~mL}$ twofold dilutions of the extracts, ranging from the MIC to a 16-fold dilution of the MIC. Ciclopirox olamine $(10 \mathrm{mg} / \mathrm{mL})$ was used as positive control. The plates were incubated for $24 \mathrm{~h}$ at $37^{\circ} \mathrm{C}$. The biofilm inhibitory concentration (BIC) was determined as the lowest concentration at which no visible growth was observed in the supernatant fluid.

Statistical analysis was performed according to Student's t-test $(p<0.05)$ in order to compare the results of the inhibition zones obtained from the oils to the ones obtained from the positive control.

\section{RESULTS AND DISCUSSION}

The antimicrobial activity of ten medicinal plants was evaluated in this work (Table 1). Seven of them have been used by local farmers in mastitis treatment while the others where chosen due to previous reports. 
Table 1. Plants used as antimicrobial in folk veterinary medicine.

\begin{tabular}{|c|c|c|}
\hline Plants & Popular names & Indication \\
\hline $\begin{array}{c}\text { Baccharis } \\
\text { dracunculifolia DC }\end{array}$ & $\begin{array}{l}\text { Alecrim-do- } \\
\text { campo }\end{array}$ & $\begin{array}{l}\text { Farmers; Alencar et al., } \\
\text { 2005; Filho et al., } 2008 .\end{array}$ \\
\hline $\begin{array}{l}\text { Chenopodium } \\
\text { ambrosioides L. }\end{array}$ & $\begin{array}{l}\text { Erva-de-santa- } \\
\text { maria }\end{array}$ & $\begin{array}{l}\text { Farmers, Albuquerque } \\
\text { et al. } 2007 .\end{array}$ \\
\hline $\begin{array}{l}\text { Cymbopogon nardus L. } \\
\text { Rendle. }\end{array}$ & Citronela & $\begin{array}{l}\text { Farmers; Koba et al., } \\
\text { 2003; Nogueira et al., } \\
\text { 2007; Simic et al., } \\
\text { 2008. }\end{array}$ \\
\hline Symphytum officinale L. & Confrei & $\begin{array}{c}\text { Farmers; Tarle et al., } \\
\text { 1982; Fenner et al., } \\
\text { 2006; Pinto et al., } 2006 .\end{array}$ \\
\hline Artemisia absinthium L. & Losna & $\begin{array}{l}\text { Farmers; Juteau et al., } \\
\text { 2003; Michelin et al., } \\
\text { 2005; Albuquerque et } \\
\text { al., } 2007 .\end{array}$ \\
\hline $\begin{array}{c}\text { Solanum asperolanatum } \\
\text { Ruiz \& Pav }\end{array}$ & Jurubeba & $\begin{array}{l}\text { Bento et al., 2004; } \\
\text { Albuquerque et al., } \\
2007 .\end{array}$ \\
\hline Salvia officinalis L. & Salvia & $\begin{array}{l}\text { Farmers; Albuquerque } \\
\text { et al., 2007; Alvarenga } \\
\text { et al., } 2007 .\end{array}$ \\
\hline Bauhinia forficata Link & Pata-de-vaca & $\begin{array}{c}\text { Silva \& Cechimel filho } \\
\text { 2002; Albuquerque et } \\
\text { al. } 2007 .\end{array}$ \\
\hline Calendula officinalis L. & Calendula & $\begin{array}{l}\text { Farmers; Viegi et al., } \\
\text { 2003; Lans et al., 2007; } \\
\text { Rozwalka et al., } 2008 .\end{array}$ \\
\hline $\begin{array}{l}\text { Dendranthema } \\
\text { grandiflorum L. }\end{array}$ & Crisantemo & Rahman et al., 2007. \\
\hline $\begin{array}{l}\text { Senna macranthera } \\
\text { (Collad.) Irwin et Barn. }\end{array}$ & Pau-fava & Data not published \\
\hline
\end{tabular}

Among the 37 plant extracts produced, only four inhibited the growth of all $S$. aureus strains evaluated. The results showed that C. nardus ethanol/water $80 \%$ extract, S. macranthera ethanol extract, A. absinthium dichloromethane extract and B. dracunculifolia ethanol/ water $80 \%$ extract could inhibit the growth of $S$. aureus strains isolated from bovine mastitis. Minimum inhibitory concentrations (MIC) of the active extracts are shown in Table 2.

Table 2. Minimum inhibitory concentrations of extracts determined by the broth microdilution method.

\begin{tabular}{lc}
\hline \multicolumn{1}{c}{ Plant extracts $(\mathrm{mg} / \mathrm{mL})$} & MIC $(\mathrm{mg} / \mathrm{mL})$ \\
\hline S. macranthera (ethanol extract) & 1.0 \\
A. absinthium (dichloromethane extract) & 1.0 \\
C. nardus (ethanol/water $80 \%$ extract) & 0.5 \\
B. dracunculifolia (ethanol extract) & 0.8 \\
Positive control* & 0.05 \\
*ciclopirox olamine
\end{tabular}

*ciclopirox olamine

C. nardus showed the strongest antistaphylococcal activity with MIC values of $0,5 \mathrm{mg} / \mathrm{mL}$, followed by $B$. dracunculifolia, MIC of $0,8 \mathrm{mg} / \mathrm{mL}$, and $S$. macranthera and A. absinthium, both with MIC equal to $1,0 \mathrm{mg} / \mathrm{mL}$. According to literature results, it is considered a strong activity when MIC values are between $0.05-0.50 \mathrm{mg} / \mathrm{mL}$, moderate activity for MIC values between $0.6-1.50 \mathrm{mg} /$ $\mathrm{mL}$ and weak activity above $1.50 \mathrm{mg} / \mathrm{mL}$ (Aligiannis et. al, 2001). Therefore, C. nardus showed strong activity, while B. dracunculifolia, S. macranthera and A. absinthium displayed moderate activity. When compared to the positive control, MIC values obtained are still low. However, the extracts produced contain not only one but a mixture of compounds among a single one or a few responsible for the biological activity, what makes necessary the identification of the most relevant substances in later studies. The values of biofilm inhibitory concentrations (BIC), determined over pre-formed biofilms, are presented in Table 3.

Table 3. Biofilm inhibitory concentrations of the active extracts.

\begin{tabular}{lc}
\hline \multicolumn{1}{c}{ Plant extracts } & BIC $(\mathrm{mg} / \mathrm{mL})$ \\
\hline S. macranthera (ethanol extract) & 0.25 \\
A. absinthium (dichloromethane extract) & 0.25 \\
C. nardus (ethanol/water 80\% extract) & 0.25 \\
B. dracunculifolia (ethanol extract) & 0.8 \\
Positive control* & 0.025 \\
\hline
\end{tabular}

*ciclopirox olamine.

The active extracts were tested in concentrations correspondent to MIC, $1 / 2 \mathrm{MIC}, 1 / 4 \mathrm{MIC}, 1 / 8 \mathrm{MIC}$ and ${ }^{1 / 16}$ MIC. The values of BIC obtained were between 0.25 and $0.8 \mathrm{mg} / \mathrm{mL}$. S. macranthera, A. absinthium and C. nardus showed BIC values equal to $0.25 \mathrm{mg} / \mathrm{mL}$, lower than the BIC obtained to $B$. dracunculifolia, $0.8 \mathrm{mg} / \mathrm{mL}$. None of the BIC values found were lower than $1 / 4$ MIC of the respective extract. Therefore, C. nardus was the extract that displayed the biggest inhibition zones and the lowest MIC and BIC values.

\section{CONCLUSIONS}

Many of the plants used by farmers in southeastern Brazil have popular indication of antibacterial activity. Our results, although, revealed only the potential of the extracts obtained from Senna macranthera, Artemisia absinthium, Cymbopogon nardus and Baccharis dracunculifolia against $S$. aureus of bovine origin. Among the seven plants indicated by the farmers for the treatment of mastitis (Table 1), $B$. dracunculifolia and C. nardus were the only ones that validated the popular use of medicinal plants in the management of the disease. Our results validate the use in folk Brazilian culture of some plants that can be easily found in our flora and some worldwide. The results support the possible use of these in the clinical management of this disease as phytotherapic agent. 


\section{ACKNOWLEDGEMENT}

The authors are thankful to Embrapa Gado de Leite, which provided the bacterial strains used in this work.

\section{REFERENCES}

Albuquerque UP, Monteiro JM, Ramos MA, Amorim ELC 2007. Medicinal and magic plants from a public market in northeastern Brazil. J Ethnopharmacol 110: 76-91.

Alencar SM, Aguiar CL, Paredes-Guzmán J, Park YK 2005. Chemical composition of Baccharis dracunculifolia. the botanical source of propolis from the states of São Paulo and Minas Gerais, Brazil. Cienc Rural 35: 909-915.

Aligiannis N, Kalpotzakis E, Mitaku S, Chinou IB 2001. J Agric Food Chem 40: 4168-4170.

Alvarenga AL, Schwan RF, Dias DR, Schwan-Estrada KRF, Bravo-Martins CEC 2007. Atividade antimicrobiana de extratos vegetais sobre bactérias patogênicas humanas. Rev Bras Plant Med 9: 86-91.

Bento AF, Azevedo MS, Luiz AP, Moura JA, Santos ARS 2004. Atividade antinociceptiva do extrato etanólico do fruto de Solanum acanthodes Hook.f. em camundongos. Rev Bras Farmacogn 14: 9-10.

Cucarella C, Tormo M.A, Ubeda C, Trotonda MP, Monzon M, Peris C, Amorena B, Lasa I, Penade JR 2004. Role of biofilm-associated protein bap in the pathogenesis of bovine Staphylococcus aureus. Infec Immun 5: 2177 2185.

Fenner R, Betti AH, Mentz LA, Rates SMK 2006. Plantas utilizadas na medicina popular brasileira com potencial atividade antifúngica. Rev Bras Cienc Farm 42: 369394.

Filho AADS, de Sousa JPB, Soares S, Furtado NAJC, Silva MLAE, Cunha WR, Gregorio LE, Nanayakkara NRD, Bastos JK 2008. Antimicrobial activity of the extract and isolated compounds from Baccharis dracunculifolia D. C. (Asteraceae). J Biosci 63: 40-46.

Gullece M, Aslan A, Sokmen M, Sahin F, Adiguzel A, Agar G, Sokmen A 2006. Screening the antioxidant and antimicrobial properties of the lichens Parmelia saxatilis. Platismatia glauca. Ramalina pollinaria. Ramalina polymorpha and Umbilicaria nylanderian. Phytomedicine 13: 515-521.

Hebert A, Sayasith K, Senechal S, Dubreuil P, Lagace J 2000. Demonstration of intracellular Staphylococcus aureus in bovine mastitis alveolar cells and macrophages isolated from naturally infected cow milk. Microbiol Lett 193: 57-62.

Johnson SA, Goddard PA, Iliffe C, Timmins B, Rickard AH, Robson G, Handley PS 2002. Comparative susceptibility of resident and transient hand bacteria to para-chlorometa-xylenol and triclosan. J Appl Microbiol 93: 336344.

Juteau F, Jerkovic I, Masotti V, Milos M, Mastelic J 2003.
Composition and antimicrobial activity of the essential oil of Artemisia absinthium from Croatia and France. Planta Med 69: 158-161.

Koba K, Sanda K, Raynaud C, Mandin D, Millet J, Chaumont JP 2003. Antimicrobial activity of essential oils of Cymbopogon citratus L. (DC) Stapf, C. nardus L. rendle and C. schoenanthus L. Spreng. J Mycol Med 13: 175180 .

Lans C, Turner N, Khan T, Brauer G 2007. Ethnoveterinary medicines used to treat endoparasites and stomach problems in pigs and pets in British Columbia, Canada. Vet Parasitol 148: 325-340.

Leite ACL, Vieira RF, Faria AR, Wanderley AG, Afiatpour P, Ximenes ECPA, Srivastava RM, Oliveira CF, Medeiros MV, Antunes E, Brondani DJ 2000. Synthesis, antiinflammatory and antimicrobial activities of new 1,2,4-oxadiazoles peptidomimetics. II Farmaco 55: 719724

Marinho ML, Alves MS, Rodrigues MLC, Rotondano TEF, Vidal IF, Silva WW, Athayde ACR 2007. A utilização de plantas medicinais em medicina veterinária: um resgate do saber popular. Rev Bras Pl Med 9: 64-69.

Michelin DC, Moreschi PE, Lima AC, Nascimento GGF, Paganelli MO, Chaud MV 2005. Avaliação da atividade antimicrobiana de extratos vegetais. Rev Bras Farmacogn 15: 316-320.

Monzon MC, Oteiza J, Leiva M, Lamata, Amorena B 2002. Biofilm testing of Staphylococcus epidermidis clinical isolates: low performance of vancomycin in relation to other antibiotics. Diagn Microbiol Infect Dis 44: 319324.

Nogueira MA, Diaz MG, Tagami PM, Lorscheide J 2007. Antimicrobial activity of essential oils and propolis against oral pathogens. Rev Cien Farm Basica Aplic 28: 93-97.

Nostro A, Roccaro AS, Bisignano G, Marino A, Cannatelli MA, Pizzimenti FC, Cioni PL, Procopio F, Blanco AR 2007. Effects of oregano, carvacrol and thymol on Staphylococcus aureus and Staphylococcus epidermidis biofilms. J Med Microbiol 56: 519-523

Pandian MR, Banu GS, Kumar G 2006. A study of antimicrobial activity of Alangium salviifolium. Indian J Pharmacol 38: 203-204.

Pinto EPP, Mello MCA, Furlan A 2006. Conhecimento popular sobre plantas medicinais em comunidades rurais de mata atlântica - Itacaré. BA, Brasil. Acta Bot Bras 20: 751762.

Rahman MAA, Moon SS 2007. Antimicrobial phenolic derivatives from Dendranthema zawadskii var. latilobum Kitamura (Asteraceae). Arch Pharmacol Res 30: 13741379.

Rozwalka LC, Lima MLRZC, Mio LLM, Nakashima T 2008. Extracts, decoctions and essential oils of medicinal and aromatic plants in the inhibition of Colletotrichum gloeosporioides and Glomerella cingulata isolates from guava fruits. Cienc Rural 38: 301-307. 
Sartoratto A, Machado AALM, Delarmelina C, Figueira GM, Duarte MCT, Rehder VLG 2004. Composition and antimicrobial activity of essential oils from aromatic plants used in Brazil. Bras J Microbiol 35: 275-280.

Silva KL, Cechimel Filho V 2002. Plantas do gênero Bauhinia: composição química e potencial farmacológico. Quim Nova 25: 449-454.

Simic A, Rancic A, Sokovic MD, Ristic M, Grujic-Jovanovic S, Vukojevic J, Marin PD 2008. Essential oil composition of Cymbopogon winterianus and Carum carvi and their antimicrobial activities. Pharm Biol 46: 437-441.

Tarle D, Petricic J, Kupinic M 1982. Antimicrobial activity of common comfrey (Symphytum officinale L.). Acta Pharm Jugoslavica 32: 235-237.

Viegi L, Pieroni A, Guarrera PM, Vangelisti R 2003. A review of plants used in folk veterinary medicine in Italy as basis for a databank. J Ethnopharmacol 89: 221-244. 